\title{
Technè, Dianoia and Mythos: Heirlooms to Comparative Study of Literature
}

\author{
*Ignatius Chukwumah, Samuel Enudi and \\ Emuejevoke Okagbare \\ http://dx.doi.org/10.4314/ujah.v15i1.2
}

\section{Abstract}

Critics have always declared the 'advantage' of comparative study of literature, namely, that it enhances the emergence of insightful and germane meanings. Yet they pass over the indispensable elements that make doing comparative criticism possible without the knowledge of the language of the various literary cultures of the works compared. To a great extent, the advantage of comparative criticism depends on the three Aristotelian concepts of techné, dianoia, mythos and their consequent interrelationships as handed down by literary traditions across genres and ages. This research, therefore, seeks to account for how these concepts enhance the comparative study of literature. It also, with an eye on these concepts, seeks to account for the influence of oral traditions on written literature from Hellenic Greek works to Nigerian literature today. Through the comparative discussion of some narratives belonging to the Nigerian literary tradition, with focus on the resilient strain necessary for comparison, this article concludes that the interaction and the bearing of these concepts within a particular creative space almost unconsciously influence an artist from whom future artists also inherit their literary codes. All these have lead to the advantage attributed to comparative study of 
literature, an advantage Nigeria literature today also gains from.

\section{Introduction}

Critics have, in the past, made several attempts to try to understand the best possible way of making texts yield their meanings. As a result, more methods of sensemaking commensurate with other disciplines are resorted to in the analysis of literature. Structuralism, one of these methods, holds that a text is enough for an analysis and that meaning and comparisons should not be a critic's ultimate goal. This was the case until comparative study of literature began in the West where it relieved or supplemented other critical approaches.

\section{Techné, Dianoia, and Mythos}

What then is 'comparative literary studies'? Several interchangeable variations of this term have been in use - 'comparative literature', 'comparative literary studies', and 'comparative criticism', though pundits have an axe to grind on the slightest variation in nomenclature. Nevertheless, they all mean reading literary texts against the other(s), as many that can fall within the realm of comparison, not only in order to discover differences and similarities as is commonly thought, but that in considering their differences and similarities, the comparatist would also derive some sort of 'scientific' model that would help in further interpreting literatures from varied traditions and ages. Elinor Schaffer noted it thus that "the inception of comparative literature as a discipline occurred in the later nineteenth century, as part of a movement towards a more 'scientific' approach 
to historical, social, and literary subjects" ("Editor's Note" Year Book 3, xi). In Schaffer's words, practitioners hoped to "arrive at Universal Principles, or generalizations universally applicable" ("Editor's Note" Year Book 3, xvii). This scientific desire was evident in Claude Levi-Strauss advocacy for anthropology ("Structural Analysis in Linguistics").

According to Hayden White, Eric Auerbach's Mimesis: the Representation of Reality in Western Literature (1968) "is a classic of comparative criticism" (Schaffer xi), which investigated how "the trope of realism" came to be so dominant and prevalent in Western literature (xi). This was his universal principle or generalization. In trying to conceptualise what one will call the lighthouse signal of what comparative literature is, she declares that its preoccupation is with method and the garnering of "requisite data to formulate theoretical conceptions of literature and to relate them to other aspects of 'civilization'" (Yearbook 2, xvii). From these declarations, we observe that comparative criticism privileges the erosion of the autonomy of an individual text (xviii).

Apart from Schaffer's point of comparative literary studies serving the purposes of theory and further investigations, Akwanya gave his when he says that:

the advantage of comparative techniques of reading [is] that the elements are seen truly as formatives and the conditions of possibility covering a range of texts and artefacts, rather than a kind of mythology 
private to the particular narrative or, as in the practices associated with psychologism, a mythology private to the artist himself (196).

From Akwanya, therefore, the gains of comparative literature help to eradicate any sort of imputed meaning, either from the critic or what critics say motivated a work's author. Thus, the meaning and principles derived from a work must only be inherent in and autochthonous to the said work. Yet, it is not made clear in these declarations what inherent properties there are in literature to warrant such attention and what eventually enables the comparatist to discover the much sought after methods or universal principles. But one does know that the sources of attractions are there and critics have always passed them over. What makes literary works so comparatively feasible could be based on the three basic concepts which are the appurtenances of the literary work, from the point of enactment of the creative art to the point of sense-making: techné, dianoia and mythos. 'Techné' is Greek term for 'craft' or 'crafting', or "the knowledge of how to do things and make things" and it is there in the word that has come down to us as technology whose derivative it is (Blackburn, "Techné"). But with Aristotle, as supported by literature, techné does not suffice in meaning by being attributable to 'technological' craft or crafting that results in the application of scientific rules. Here, the material for crafting is solid, the third element matter is consisted of. More than this and in literature, techné informs the crafting of a text using language either in the oral or 
written medium at a plane where language's denotative power is blunted, yet is haunted by history and echoes. It is at the point where echoes and traces of words in a language suffuse that dianoia begins to take on a life of its own unarmed for signification as "free speech, speech unburdened of its signalising functions" (Derrida 12). Techné begins as an interactive force with mythos and dianoia as its final product. Throughout this study, therefore, techné shall be implicit in the discussion of mythos and dianoia.

Dianoia means 'thought'. Yet, it is not similar to the idea of thought derived from a piece of information encoded by conventional language, a philosophical text. The above is function-driven and function-directed. Dianoia brings to mind "the idea of the poetic thought" (Frye, Anatomy 52). This sort of thought is headed to nowhere; it just gets excited and gathers in a pool of imagery like metaphors, symbols and figures in a poem, a sequence, a chapter or in an entire literary work irrespective of the genre. It is easily identifiable in poetry. Dianoia is part of the ingredients that make up the six cardinal or classical Aristotelian elements of tragedy. Modernist works would rather have them in pastiches and in collages like Eliot's "The Waste Land", "Prufrock"; Rilke's Duino Elegies, the later Wizlawa Szymborska's poetry; Osip Mandelstam's The Stone (1913) and Tristiya (1922); Hugo von Hofmannsthal's Gestern (Yesterday); and other poems. It is what Frye has called "a secondary imitation of thought, a mimesis logou" that is provoked by "images, metaphors, diagrams, and verbal ambiguities" (Frye, Anatomy 83). These are given 
in literature via techné in a unique manner within the humanities. Humanities' other areas, like the plastic arts, dramatic arts and music have their various media of imitation as pointed out by Aristotle in his Poetics. But within the manner of imitation of poetry, which is language, dianoia assumes mobility from a beginning and towards an end. It is at the end that the mythos, the structure formed as the reader captures the import of a narrative, manifests fully and becomes apparent as a plot. The mythos enunciates the thematic 'sentence' comprising the NP[Noun Phrase] + VP[Verb Phrase] format through characters' actions.

As a twin voluntary intent of techné, dianoia being the first, mythos does not gather a pool for a brood. It mostly implicates a narrative pattern, and patterns are not arrived at without a movement. This was intended in Aristotle when he says that a fable must have a beginning, middle and an end. From the beginning to the end entails a movement of some sort - in and by readers. Frye, in reinterpreting Aristotle and in illustrating the twin relationship between mythos and dianoia, posits thus:

a painting may be studied as the track of an intricate dance of the eye. Works of literature also move in time like music and spread out in images like painting. The word narrative or mythos conveys the sense of movement caught by the ear, and the word meaning or dianoia conveys, or at least preserves, the sense of simultaneity 
caught by the eye. We listen to the poem as it moves from beginning to end, but as soon as the whole of it is in our minds at once we "see" what it means. More exactly, this response is not simply to the whole of it, but to $a$ whole in it: we have a vision of meaning or dianoia whenever any simultaneous apprehension is possible (77-78).

With this inter-relationship of these two terms thus established, one should be acquainted with what brings them into being, the creative act, techné; and the only way through which this is done is language. Correlatively, these concepts, but chiefly mythos, establish the possibility of comparative literature.

The French school of comparative literature hold that comparative literature should only be undertaken when an adequate formal knowledge of the literary tradition of works to be compared and their languages have been had (Kos 31). This means that a Nigerian comparatist working on Stendhal, Mallarme and Joseph Conrad must have a prerequisite knowledge of French language. This rule had been followed in some academies, a situation that hangs as a shadow of compulsion over the heads of interested comparatists. Later, some academies started regarding this condition with a waiver giving as their reason the ready availability of translations of these works. This research claims that this dismissal or relaxation of a once tightly-held rule, especially by the American practice of comparative literature, though 
unstated, is as a result of the presence of perceptible dianoia and mythos in the various literary traditions that techné has brought forth and which literature has inherited.

\section{'Textualising' Tradition through Dianoia and Mythos}

Literary creations derived from the oral domain, through techné, have been handed over to us. The greatest Greek tragedians are Aeschylus, Sophocles and Euripides in their generational order. They are also in the habit of recreating and interpreting these tragedies whose loci are not far-fetched and which are of common knowledge in the oral domain. An example is the Oedipal and postTrojan fables.

Aeschylus is the author of many plays that included Prometheus Bound, Laius, Oedipus, Eumenides and Seven Against Thebe while Euripides wrote Hecuba, Hyppolytus, Orestes. Aeschylus' successor and Euripides' predecessor, Sophocles, has Antigone, Electra and Oedipus Tyrannus. In the representation of the feud of Oedipus's children after their father was long gone is given in Aeschylus' Seven Against Thebes. The same fable or mythos containing its dianoia because of their dominance in the oral domain gets represented by Sophocles, a later poet in Antigone. Of course, differences are expected to be found. In Aeschylus, Antigone is supported by a band of sympathisers in disobeying Creon to bury Polyneices while in Sophocles, she is alone. Once more, the fable of the domestic tragedy that takes place in Agamemnon's family is also 
multi-represented by poets of different generations. Electra is Sophocles representation of the vengeance of Orestes and Electra on their mother, Clytemnestra and her lover, Aegisthus who both conspire to kill Agamemnon on his return from the siege of Troy. This has already been given at a far earlier work in Homer's The Odyssey when Menelaus narrates his homecoming to a father-seeking Telemachus. Euripides has done same with his Orestes. But in Aeschylus's Euminides, a segment of this oral fable as it pertains to the punishment of Orestes by the Furies has been represented by the foremost tragedian about a hundred years before. In addition, much earlier, say about four hundred years, Homer had mentioned Oedipus in connection to Epicaste, or Jocasta as we later know her in The Odyssey when Odysseus is in Hades to seek counsel of Teiresias. The Hades is, no longer to Odysseus, the place of permanence; rather, it is more of what Adekoya has called in reference to Sekoni's philosophy in Soyinka's The Interpreters as "the abyss of transition" (181). In the same vein, the Trojan War, Ilium, Odyssey, the sack of Troy is mentioned by Ovid's Metamorphosis about eight hundred years after it was mentioned by Hesiod and Homer. From all these, we can manage out an idea: that the oral domain has been pre-eminently domineering on written discourses in the literatures of the Classical Hellenic era and the form of this force is supplied by mythos and dianoia. Aristotle supports this claim when he said that "in these days the finest tragedies are always on the story [mythos] of some few houses, on that of Alemeon, Oedipus, Orestes, Meleager, Thyestes, Telephus, or any others that may have been involved, as 
either agents or sufferers, in some deed of horror" (Aristotle, The Poetics).

These multi-faceted representations can be rightly seen as interpretations (Ricoeur, The Conflict of Interpretations 27). These interpretations focus on the oral text, an expansive and protean body of tradition, and adapting same into some written texts. In the process of adaptations, techné carries dianoia and mythoi into its form. Here is how Ricoeur puts it:
A tradition exhausts itself by mythologizing the symbol; a tradition is renewed by means of interpretation which reascends the slope from exhausted time to hidden time, that is, by soliciting from mythology the symbol and its store of meaning (29).

He goes further to explain what this interpretation means and does: "interpretation does not spring from nowhere; rather, one interprets in order to make explicit, to extend, and so keep alive the tradition itself, inside which one remains ... the continual interpretation of this deposit: our "heritage'" (27). So these Grecian tragedians were engaging in interpretation of their tradition in their representations, and by so doing, have kept it alive despite the interregnum that separates one from the other.

Moreover, we understand also that "true Tragedy had always taken its material from the sacred myths, or heroic sagas, which to the classical Greek constituted 
history. But the New Comedy was in the habit of inventing its plots" (Murray, "Preface."). Till date, we have not been estranged from this spell of New Comedy, for tradition is now solely reliant on the invention of plots. Another reason why this inheritance has dominated literary traditions so much is that sagas and myths depended on plots for elaborations without which they would not be. This inheritance appears also to be authenticated by the usage of historical names, the NPs of those narratives. As Murray has said about the last two terms, "tragedy adheres to 'the historical names' for an aesthetic reason, because what has happened is obviously possible and therefore convincing" ("Preface").

With this networking taking place in faraway Greece of the Classical era, reasons abound that what was begun would continue. In Nigeria's literary tradition, the Ogbanje myth with the mythos of death-revival, conventionally, a concept that is resident in the oral domain has had a consistent mentioning and imbuing of thoughts in written works. This concept denotes different things amongst the Yoruba of Western Nigeria who term it $A b i k u$. It supplied the structural relevance of such works as Soyinka's Ake, "Abiku"; J.P. Clark's "Abiku", Ben Okri's The Famished Road, to a lesser extent, Chinua Achebe's Things Fall Apart, and, to a greater extent, Toni Morrison's Beloved. The abiku is just an instance. Another is the pantheon of Yoruba gods, which, originally, are the property of the oral domain, but have individually and as a group, like in Soyinka's The Interpreters, been trapped by the written literary 
tradition. Many have followed Soyinka to convolute these. Yet it is still the same concept as in the case of abiku that is given perspectival motivations to the above works. As McCabe supports, "abiku writings constitute a major tradition within Nigerian literature" with "at least thirty works in which abiku or ogbanje play some sort of pivotal role" (45). It is as much a potent phenomenon in our tradition as the incident of Troy in the pre-classical and Hellenic Greco-Roman literary tradition.

Besides being seen as the transmitter of "oral culture through writing", the twin works of Things Fall Apart and Arrow of God posit the "legends of Okonkwo and Ezeulu, of Umuofia and Umuaro", respectively. Through these, Achebe takes "into account not only what has happened but also what is fabled to have happened. He re-constructs the history of his people largely by drawing on myth and legend" (Thieme 9). The mythos here is that of one's fall from a high degree. Another example is Niane's Sundiata. The difference between a thrilling, rich and unabridged account of Sundiata's life in English in D. T. Niane's Sundiata: An Epic of Old Mali (1965) and some other general historical accounts like A. Adu Boahen's Topics in West African History (1966), and Basil Davidson's A History of West Africa to the Nineteenth Century (1965) is the instance of the oral sphere serving as ground and mythos for the written epic.

The greater the influence of the oral domain, the more they embody the twin concepts of dianoia and mythos in reaching what Jeyifo frames as "unified construct" (19). These two concepts are passed unconsciously from age 
to age, however original the works might be, implying Bloom's "anxiety of influence" (Eagleton 158). With the dianoia and mythos embedded in a tradition and unconsciously handed over thus and with "the doublings and sliddings of language", the forming layers of secondary revisions, preventing any text, in its tradition, from, in a very subtle manner, revealing and concealing all at once is impossible (159).

At the core of this dallying and instability of meaning is a sub-text that criticism must endeavour to get at - the repressed. It is this sub-text, 'Oedipal complex', in Freudian terms, which Bloom articulates as influence ("Harold Bloom."). The oedipal influence therefore is but a metaphor of how tradition in utter abhorrence of the former ends up being more like the former which it detests. Following this argument in the instance of this article, the oral domain will not feign difference from the written sort. To Bloom, the repressed, appearing in form of dianoia and mythos, is the inescapable and inevitable products of techné ("Harold Bloom."). Interestingly, it is from here that the gains of comparative study of literature have shown forth since in reading literature, one is able to trace how the movement of dianoia provokes the progress of the mythos, whether in poetry or prose. The character, the NP that enunciates the VP, reacts to it in a stimulus-response format.

The instance of a mythos where an individual meets with what he tries all his life to avoid, inescapability, is evident in Sophocle's Oedipus Tyrannus and Achebe's Things Fall Apart. But let us analyse the case of the 
mythos of suicide. Suicide itself as an act, which Oedipus falls short of doing, but which in any case is symbolised in the pulling off of his eyes, is a manifestation of the plenitude of unbearable circumstances an individual is immersed in, some sort of an existential border situation. As an act traceable to its archetype in Judas lscariot in Judaeo-Christian discourse, it is done as a direct or indirect consequence of suffering. Either the individual has sinned against himself, an Other, or he has been offended. In Umuofia, although it is forbidden, it is subtly contradicted in their folk tradition as embodied in their myth. The consequences of "how leaves become smaller after cooking" suggest the presence of suicide in the Umuofia's worldview (Achebe 59). The lizard kills his mother when he finds only three baskets of vegetables remained after giving her seven to cook. He goes ahead to commit suicide too, after similar number of baskets is left after cooking them himself. His suicide is a direct consequence of his mother's death. Another instance of a man who ties his cloth to a tree branch and hangs himself because seed yams are destroyed after a spell of sunshine does appear as an example of a proto-Okonkwo's suicide in Things Fall Apart. He has been sinned against, this time by nature. Suicide, here, is the end chain of a sequence of interlocking sin, leaving the thought-provoking question of whether desecration must be resorted to to stave off desecration to generate unanswerable aporias. His body being evil requires "sacrifices to cleanse the desecrated land" (147). His suicide is in relation to rejection, his exclusion. His rejection is almost in relation to the mythos of exclusion which, in Prometheus Bound, 
Prometheus, who is excluded from the divine community because of his sympathy toward man, figures. Unlike Prometheus, who is from the community of the divine, Okonkwo's exclusion is psychological in the manner of opinions and beliefs.

In summary, whether in works like Oedipus Tyrannus, Things Fall Apart or tragically ironic works such as The Interpreters and The Famished Road, the fate of the individual is more than he could control. In Oedipus, it is knowledge; in Okonkwo, it is changing history, in the others, it is the unbearable burden of either poverty, the inexplicable spiritual condition or that which is not definite - all under the services of dianoia and mythos.

\section{Dianoia, Mythos and Habila's Waiting for an Angel}

Helon Habila's Waiting for an Angel can be properly termed a work belonging to the Nigerian novel, and as such, the literature of today - works of the twenty-first century, at least. The mythos of Prometheus resurfaces in this work as it does in some Nigerian works of this period. It seems to be dialectically related to the mythos (plot) of castration which is also the atmosphere hanging around the whole of this text. The personages that bear the dianoia in several parts of the text are Lomba, Kela, James Fiki of The Dial, Mao, Joshua, Hagar, and the journalists, on the one hand, and the government, the police authorities, and other agents of the government, on the other. While the first group are members of the oppressed, the prey of the mighty, they are nonetheless of a special breed of oppressed persons in that they not only seek to cast off the yoke of oppression and bondage 
for themselves; they also seek to extend these presages of freedom to all members of their society by calling them to the awareness of their rights to freedom. As dianoia, they serve as metaphors and figures of good fighting agents of evil. They use various channels to actualize this: to Lomba and Kella, it is a peaceful protest; to James Fiki and other journalists like Dele Giwa, it is through the power of the pen; to Kudirat, it is through public criticisms and abhorrence of the government's pretension to legitimacy. The bold stand of these several persons for their society makes them fit into the plot pattern of Prometheus, its mythos, and it is based on this stand that pain and suffering are inaugurated in Waiting for an Angel.

Each individual's activity calls for brooding like the metaphors that they are. By littering the text, they help shape the plot. In fact, the plot or structure, that is, mythos is never and can never be sustained without them. They are the mood of resistances that one finds, in comparative terms, in The Famished Road's Dad, the Ijaw youths of Niger Delta in Agary's Yellow-Yellow. In the last work, it is evident in such distant characters as Zilayefa whose attitude and response can be seen as supporting a mythos in Prometheus Bound as she resists her mother's principles and descends into abnormal sexual behaviours. The same mythos is identified in Dibia's Unbridled with Princess, Uloma, Tiffany, Uncle Kachi in Nigeria and James King (though he fails) and Providence in England. In the same vein, these characters serve as dianoia or figures whose activities in the work help in forming the mythos of resistance. 


\section{Conclusion}

From above, it is fitting to assert that the services of dianoia and mythos are not negligible in any way in the practice of comparative studies of literature. From this sort of comparative analysis, interpretive devices can be built which would further help in analyzing other works. In the words of Schaffer, it would then help in gathering the requisite data to formulate theoretical conceptions of literature and to relate them to other aspects of 'civilisation'. Nigerian narratives belonging to this decade are one of those aspects of Schaffer's civilisation. This article concludes that the influences of an artist, from the ancients to those of now, no matter the tradition, are made possible because of the activity, interaction and the bearing of the trivet concepts of techné, dianoia and mythos in the artistic space. These, substantially, have led to the advantage ascribed to comparative study of literature in our present time.

Ignatius Chukwuma is of the Department of English \& Literary Studies, Federal University, Wukari, Taraba State, Nigeria, While Enudi \& Okagbare are of the General Studies Department, Delta State Polytechnic, Otefe, Oghara, Delta State, Nigeria. 


\section{Works Cited}

Achebe, Chinua. Things Fall Apart. London: Heinemann, 1958.

Adekoya, Segun. The Inner Eye: An Oriel on Wole Soyinka's Works. Ife: Obafemi Awolowo University Press, 2006.

Akwanya, A.N. Language and Habits of Thought. Enugu: New Generation, 2005.

Aristotle. Trans. Ingram Bywater. The Poetics. Project Gutenberg. 2009. 22 May, 2010. <www.gutenberg.org/6763.h-zip/6763-h/6763h.htm>.

Buckley, T.A. "Preface." Euripides. The Tragedies of Euripides: Volume I. February 16, 2005. 22 May, 2010. <www.gutenberg.org/15081.h-zip/15081h/15081-h.htm>.

Derrida, Jacques. Writing and Difference. Chicago: University of Chicago Press, 1978.

Eagleton, Terry. Literary Theory: An Introduction. 2nd ed. 1983. Oxford: Blackwell, 1996.

Habila, Helon. Waiting for an Angel. Lagos: Cassava Republic Press, 2002.

Jeyifo, Biodun. Wole Soyinka. Cambridge: Cambridge University Press, 2004.

Kos, Jauko. A Comparative History of Slovenia Literature. Ijubljana: ziff Partizanskab Knjiga, 1987.

Levi-Strauss, Claude. "Structural Analysis in Linguistics and in Anthropology." Structural Anthropology. The Penguin,1968. 13 Nov. $2008<$ http://www. 
marxists.org/reference/

/subject/philosophy/works/ru/levi-strauss.htm>.

McCabe, Douglass. "Histories of Errancy: Oral Yoruba abiku Texts and Soyinka's "Abiku". Research in African Literatures. 33.1 (2002): 45-74.

McPheron, William. "Harold Bloom." 1998. Stanford Presidential Lectures and Symposia in the Humanities and Arts. 2 Apr. 2009 $<$ http://prelectur.stanford.edu/lecturers/bloom/ind ex .html>.

Murray, Gilbert. "Preface." Aristotle. Trans. Ingram Bywater. The Poetics. Project Gutenberg. 2009. 22 May, 2010. <www.gutenberg.org/6763.hzip/6763-h/6763-h.htm>.

Schaffer, S. Elinor. "Editor's Note." Comparative Criticism: Year Book 2. Cambridge: Cambridge Universtiy Press, 1980.

"Editor's Note." Comparative Criticism: Year Book 3. Cambridge, UK: Cambridge University Press, 1981.

Soyinka, Wole. The Interpreters. London: Fontana, 1972.

Thieme, John, ed. Contemporary Commonwealth Fiction. ACLALS Bulletin. 8th Series. No.1. London: Dangaroo Press, 1989. 